\title{
The Effects of Economic Freedom on Firm Investment in Vietnam
}

\author{
Anh Hoang LE*, Taegi KIM** \\ Received: June 30, 2019 Revised: December 11, 2019 Accepted: December 18, 2019
}

\begin{abstract}
This paper investigates how economic freedom affected firm investment in Vietnam. In the globalization decade, economic freedom has been an important policy to support economic development in Vietnam. Improvements in economic freedom, such as capital freedom and domestic credit freedom, allow firms to access external finance more easily, so that the firm's investment depends less on internal cash flow. In a developing country, on the drawbacks, many small and medium firms likely have more challenges if the government would not give any subsidies. The higher level of freedom may exacerbate the financing constraints of less competitive firms. We analyze unique firm-level data from 2006 to 2016 , which includes listed firms on two major stock exchanges and unlisted firms in the Unlisted Public Company Market. The article also considers how economic freedom affects small firms and large firms differently. Our results show that capital freedom and domestic credit freedom played an important role in investments for Vietnamese firms. However, we cannot find evidence that overall economic freedom relaxed the financial constraints on firms. Additionally, we suggest that small firms likely gain more advantage in access to external finance than do larger firms when the government removes restrictions from capital movement and the domestic credit market.
\end{abstract}

Keywords : Investment, Economic Freedom, Cash-flow Sensitive, Financial Constraints, Vietnam

JEL Classification Code: E22, G31, O16

\section{Introduction}

In a globalization era, the economic freedom index is a key variable in numerous research papers. The topic has been calling for considerable attention from many scholars. For example, researchers in the fields of economic development, income equality or human development, or the environment could use economic freedom as a potential idea for their research. In a review of current literature on economic freedom, Hall and Lawson (2014) find that more than two-thirds of 198 empirical articles confirm the positive effect of economic freedom on the economy. For

${ }^{*}$ First Author. PhD student, Department of Economics, Chonnam National University, Republic of Korea.

Email: anhlebanking@gmail.com

${ }^{* *}$ Corresponding Author. Professor, Dept. of Economics, Chonnam National University, Korea [Postal Address: 77 Yongbong-Ro, BukGu, Gwangju, 500-757 Korea]

Tel. 82-62-530-1455, Email: tgkim@jnu.ac.kr

() Copyright: The Author(s)

This is an Open Access article distributed under the terms of the Creative Commons Attribution NonCommercial License (https://creativecommons.org/icenses/by-nc/4.0/) which permits unrestricted noncommercial use, distribution, and reproduction in any medium, provided the original work is properly cited. example, De Haan and Sturm (2000) compare different approaches to measure economic freedom and investigate the role of economic freedom in economic growth. Their research shows that a higher ranking of economic freedom is followed by higher economic growth. In particular, firms' investment is a crucial determinant affecting economic growth. A recent study of Erum, Hussain, and Yousaf (2016) also emphasizes the important and reliable contribution of domestic private investment to economic growth. Therefore, it is important to do further research on the link between economic freedom and firm investment.

The purpose of this paper is to examine the effect of economic freedom and its major sub-components, such as capital freedom and domestic credit freedom, on firms' investment in Vietnam. An economy can be characterized as having more economic freedom if the government makes just enough regulations to protect human rights. Along with the economic-freedom process, the government likely removes its control on capital movement and the credit market. A predictable outcome is that economic freedom gives people more rights to their assets and labor, which motivates firms to expand their business. Additionally, improvements in capital freedom create more equal 
opportunities for both domestic and foreign economic enterprises.

In a dynamic economy, financial constraints can be relaxed because of the development of financial institutions and a reducing of asymmetric information. However, some authors argue that domestic firms will face more challenges during liberalization and globalization. Particularly, small and medium enterprises which play an important role in the developing country are usually subsidized by the government. Jumping into a free market, these firms have to compete with foreign firms without any subsidies. For example, the interest rates may go up to reflect the demand and supply of credit when the government eliminates an interest rate ceiling, which, as a consequence, raises the cost of external finance for less competitive firms. This forces firms' investment to depend more on internal cash flow. Especially, the regulatory components of economic freedom would worsen many economic problems, such as credit crunch, during crises or any exogenous economic shocks (Bjørnskov, 2016). Therefore, the effect of economic freedom on the investment behavior of firms may be ambiguous.

We employ an Euler equation model and use panel data for Vietnamese firms, including listed firms in Ho Chi Minh City Stock Exchange (HOSE) and Ha Noi Stock Exchange (HNX), and unlisted firms in the Unlisted Public Company Market (UPCoM). Economic freedom and its subcomponents are from the Fraser Institute's Economic Freedom of the World index. We also consider the different effects of economic freedom on accessibility to external fund on firms by considering the effect of firm size.

The paper will proceed as follow. Section 2 reviews the current literature. Section 3 introduces the model and describes the data. Section 4 discusses the estimate results. Section 5 is a conclusion.

\section{Literature Review}

Logically, economic freedom removes obstacles and barriers in the economic and financial market, which likely motivates firms to increase their investment. When the government creates a fair market for various economic parties and lets the market operate itself, asymmetric information also reduces. Consequently, external finance costs decrease. In contrast, less competitive firms have already faced many challenges. In addition, other strong firms compete in the market after the reduction of restrictions on investment and credit regulations, which exacerbates the financing constraints of less competitive firms.

Modigliani and Miller (1958) state that the firms' investment decisions are not relevant to the financing decisions in the perfect capital and credit markets. However, in an imperfect market, such as in a developing country, firms' investment not only heavily depend on their cash flow, but the external funds also play a very important role in firm growth. Calomiris and Hubbard (1995) find that firms' investment depends on both internal finance and macroeconomic credit conditions. Musso and Schiavo (2008) investigate the effect of financial constraints on firm survival and growth. They show that the growth of firms is significantly supported by the ability of a firm to access external financial resources. Similarly, Zhang and Yin (2018) implies that improvement in the financial market, such as remove entry barriers and create a fairly competitive environment among banks, positively affects firms' investment efficiency in an emerging country.

According to Cleary (1999), a highly creditworthy firm's investment depends heavily on internal funds, whereas a less creditworthy firm's investment is less dependent on internal fund. This result supports the previous study of Kaplan and Zingales (1997), which shows that the effect of cash flow on investment by the financially least-constrained firms is higher than that for the financially moreconstrained firms. In contrast, Beck, Demirgüç-Kunt, and Maksimovic (2005), Mulier, Schoors, and Merlevede (2016) find that financing obstacles are higher for a small firm than for a large firm. Their result also implies that a moredeveloped financial system and less corruption can lower the financing obstacles that firms face.

Whether capital freedom can mitigate firms' financing obstacles is under debate. A country receives a higher rating in capital freedom if it removes barriers for the physical and human capital movement (Gwartney, Lawson, \& Block, 1996). Predictably, as capital movements are liberalized in a country, it likely attracts a higher volume of foreign capital inflows during the opening process. In a competitive market, domestic firms sometimes have fewer comparative advantages than do foreign firms. If both domestic firms and foreign firms borrow money in the host-country credit market, that will worsen domestic firm constraints.

This issue is proven by the empirical research of Harrison and McMillan (2003), which uses firm-level data for the Ivory Coast. However, as more capital flows into a country, the domestic credit market is more abundant. Using a larger sample that combines cross-country firmlevel data, Harrison, Love, and McMillan (2004) find that global capital removes the domestic firms' financing constraints. Empirical research for China from 2000 to 2002 by Héricourt and Poncet (2009), focusing on Direct Foreign Investment and credit constraints, also finds that the relationship between domestic firms and foreign firms removes the private domestic firms' financing and legal obstacles.

There are also debates about whether higher credit 
freedom may reduce or augment the effect of cash flow on firms' investment. Based on the Fraser Institution approach, a country which allows banks freedom to allocate credit and lets the credit market decide the interest rate gets a higher rating for credit freedom. Deregulation, in some cases, is argued to be a source of economic problem, such as economic crises, because firms and individuals are not always rational (Bjørnskov, 2016; Stiglitz, 2009). They find that deregulation, especially in financial sectors, is likely to be associated with higher risk and credit crunch. As a consequence, banks increase the lending interest rate. Predictably, the least creditworthy firms are more dependent on internal funds. Recently, Nguyen and Nguyen (2020) suggest that high-interest expenses can force small and medium enterprises in Vietnam under financial distress. In addition, Koo and Maeng (2005) also find different effects of financial liberalization on accessibility to credit between different firms. They find that small and nonchaebol firms gain more benefit than do large firms from deregulation.

\section{Research Methods and Data}

\subsection{Data Description}

The economic freedom index is measured by the Fraser Institute's Economic Freedom of the World index. This index is created by Gwartney et al. (1996). All data is available for many different countries since the 1970s. The overall index reflects the degree of freedom in five major areas, including the size of government, the legal system and security of property rights, sound money, freedom to trade internationally, and regulation. The rating in each area is measured by several components and sub-components. A higher economic freedom index accompanies less regulation and restrictions in the economy.

For further investigation, we employ two subcomponents, which are the controls on the movement of capital, and credit-market regulations. These indices present the capital liberalization and domestic financial freedom, respectively. The higher value is for a higher level of freedom. If the government removes barriers from foreign investment and allows foreigners to own a higher proportion of shares of domestic firms, the country gets a higher score in capital freedom. Similarly, freedom in the credit market means that there is less state ownership in the banking sector and few controls on borrowing and lending. Increasing the proportion of deposits and credit to the private sector implies higher credit freedom, and results in higher ratings. In contrast, low credit freedom indicates more central planning and restrictions on the interest rate.

Table 1 shows the degree of freedom for capital, domestic credit, and overall economic environment in Vietnam from 2006 to 2016. As can be seen, the capital freedom rating is lower than $3 / 10$, whereas the domestic credit freedom fluctuates around $9 / 10$; these numbers indicate that Vietnam has more controls on the movement of physical and human capital, but put fewer controls on domestic credit to private sectors and on the economy in general. Additionally, the capital freedom index and credit freedom index have higher volatility than does the overall economic freedom index.

Table 1: The freedom index over time

\begin{tabular}{|c|c|c|c|}
\hline Year & Capital freedom & Credit freedom & Economic freedom \\
\hline 2006 & 2.47 & 9.47 & 6.31 \\
\hline 2007 & 2.38 & 9.54 & 6.3 \\
\hline 2008 & 1.99 & 8.99 & 6.19 \\
\hline 2009 & 1.85 & 9.61 & 6.45 \\
\hline 2010 & 2.22 & 9.63 & 6.33 \\
\hline 2011 & 2.22 & 9.08 & 6.24 \\
\hline 2012 & 2.37 & 9.15 & 6.4 \\
\hline 2013 & 2.41 & 9.14 & 6.37 \\
\hline 2014 & 2.67 & 9.14 & 6.32 \\
\hline 2015 & 2.31 & 8.87 & 6.3 \\
\hline 2016 & 2.24 & 8.95 & 6.42 \\
\hline Std. Dev & 0.2136 & 0.2643 & 0.0732 \\
\hline
\end{tabular}

Source: https://www.fraserinstitute.org/economic-freedom/dataset

Firm data is collected from financial statements of Vietnamese listed and unlisted firms on the Ho Chi Minh City Stock Exchange (HOSE) and Ha Noi Stock Exchange (HNX), and of unlisted firms in the Unlisted Public Company Market (Upcom), from 2006 to 2017. All the necessary variables for the investment model are calculated as presented in Appendix A.1.

Following Gilchrist and Himmelberg (1998), GochocoBautista, Sotocinal, and Wang (2014), Love (2003), and Tran and Le (2017), we remove observation with $\mathrm{I} / \mathrm{K}>2.5$ or $\mathrm{S} / \mathrm{K}>20$ or $\mathrm{CF} / \mathrm{K}<-1$ or $\mathrm{CF} / \mathrm{K}>1$ (where $\mathrm{I} / \mathrm{K}$ is investment to capital, $\mathrm{S} / \mathrm{K}$ is sales over capital, and $\mathrm{CF} / \mathrm{K}$ is cash flow to capital). There are only firms which report at least five continuous observations maintained in the data. Finally, outliers is eliminated in the data using the BACON command on Stata, which is an effective way to detect outliers in multivariate data based on Mahalanobis distance (Weber, 2010). The final data are unbalanced panel data, which consists of about 397 firms and 2894 observations.

We also investigate the bias effect of freedom on the characteristics of firms. To measure firm size, we calculate the average of capital at the beginning of each year for 10 industries (Industry classification; see as Appendix A.2). For 
each year, a firm is classified as a large firm if its capital is higher than the average capital, otherwise as small. According to the classification, more than 75 percent of the observations is of small firms. Table 2 shows that the average ratios are higher for small firms than for large firms.

Table 2: The freedom index over time

\begin{tabular}{|c|c|c|c|c|}
\hline Whole sample & No. Obs & No. Groups & Mean & Std. Dev \\
\hline I/K & 2894 & 397 & 0.1585 & 0.3905 \\
\hline S/K & 2894 & 397 & 4.5359 & 3.9335 \\
\hline CF/K & 2894 & 397 & 0.2699 & 0.2604 \\
\hline Large firm-year & \multicolumn{5}{|l}{} \\
\hline I/K & 645 & 127 & 0.1308 & 0.3824 \\
\hline S/K & 645 & 127 & 2.9089 & 3.1580 \\
\hline CF/K & 645 & 127 & 0.1911 & 0.2212 \\
\hline Small firm-year & \multicolumn{5}{|l}{} \\
\hline I/K & 2249 & 348 & 0.1665 & 0.3925 \\
\hline S/K & 2249 & 348 & 5.0025 & 4.0097 \\
\hline CF/K & 2249 & 348 & 0.2925 & 0.2664 \\
\hline
\end{tabular}

Note: The total number of large firms and small firms is greater than the total firms in the whole sample because a firm can be classified as large in one year, small firm in another.

\subsection{Model Introduction}

In this paper, we use OLS regression with panel-clustered standard errors. To measure the specific effect of time and industry, we also use year and sector as dummy variables. We develop the model based on the Euler equation in the linear form. First, the basic model (equation 1) aims to test the firm's investment behavior for the whole sample. Second, we add an interaction term between the level of freedom and cash flow (equations 2 and 3) to test whether higher freedom reduces financial constraints.

Basic model:

$$
(I / K)_{i t}=c+\beta_{1}(I / K)_{i t-1}+\beta_{2}(S / K)_{i t}+\beta_{3}(C F / K)_{i t}
$$

Augmented model with the level of freedom:

$$
\begin{aligned}
& (I / K)_{i t}= \\
& \beta_{3}(C F / K)_{i t}+\beta_{4}(C F / K)_{i t} * F R E
\end{aligned}
$$

Model with firm-size effect:
$(I / K)_{i t}=c+\beta_{1}(I / K)_{i t-1}+\beta_{2}(S / K)_{i t}+\beta_{3}(C F / K)_{i t}+$ $\beta_{4 l}(C F / K)_{i t} * F R E * L A R G E+\beta_{4 s}(C F / K)_{i t} * F R E *$

SMALL

where FRE is an indicator for the freedom index, including the economic freedom index, capital controls rating, and domestic credit freedom index. LARGE take the value of 1 if capital of a firm for the year is greater than the industry average, zero otherwise. SMALL take the value of 1 if the capital of a firm for the year is not greater than the industry average, zero otherwise.

\section{Results and Discussion}

Tables $3 \mathrm{a}$ and $3 \mathrm{~b}$ present the regression result for the whole sample and for the regression with the firm-size effect, respectively. Most of the parameters shown in the expected sign are statistically significant. The coefficient of lagged value of $\mathrm{I} / \mathrm{K}(\beta 1)$ and the coefficient of $\mathrm{S} / \mathrm{K}(\beta 2)$ are positive and significant at $5 \%$ in all the regressions, that is, the current investment to capital has a positive correlation with the previous investment to capital. If a firm has a higher investment to capital previously, it would likely have higher ratio of investment to capital in the current period.

The result implies that firms maintain their investment behavior over time, as is consistent with previous papers, such as Koo and Maeng (2005) and Love (2003). Additionally, ratio of sales to capital, which captures the growth opportunities, is an important variable in the firminvestment models. The positive coefficient means that a higher ratio of sales to capital is followed by a higher investment to capital. With a positive sign $(0.2590)$ and significance at $5 \%$ in the regression for the basic model, cash flow to capital is a good indicator for the financial constraints of Vietnamese firms. Investment ratio in the current year depends on the cash flow generated in the previous year.

For the economic freedom index, there is no evidence that higher overall economic freedom relaxes the financial constraints for firms. However, capital liberalization and domestic credit freedom have a strong effect on a firm's financial constraints. A significant and negative $\beta 4$ shows that higher capital freedom and domestic credit freedom reduce the cash flow sensitive to investment. The result implies that improvements in financial regulations encourage firms' investments in Vietnam, as is consistent with the study of Modigliani and Miller (1958) about the role of external finance in firms' investment in an imperfect market.

Comparing the significant coefficients $\beta 41$ and $\beta 4 \mathrm{~s}$ in Table $3 \mathrm{~b}$, the coefficient for $\mathrm{CF} / \mathrm{K}^{*} \mathrm{FRE} * \mathrm{SMALL}$ is higher 
than the coefficient for $\mathrm{CF} / \mathrm{K}^{*} \mathrm{FRE}$ *LARGE, which means that domestic credit freedom and capital freedom have a more positive effect on the financing constraints of small firms than on those of large firms. Following capital liberalization and domestic credit deregulation, the small firms increase their relative advantage in access to external finance. The finding is consistent with the results in Koo and Maeng (2005), but contrast with the results in Tran and Le (2017).

Table 3a: Regression Result (whole sample)

\begin{tabular}{|c|c|c|c|c|}
\hline & Basic Euler model & Economic freedom & Capital freedom & $\begin{array}{l}\text { Domestic credit } \\
\text { freedom }\end{array}$ \\
\hline \multirow{2}{*}{ cons } & $37.9941 * * *$ & $38.8090 * * *$ & $29.4267 * * *$ & $47.5148^{* * *}$ \\
\hline & $(5.22)$ & $(5.36)$ & $(3.84)$ & $(5.57)$ \\
\hline \multirow{2}{*}{ L.I/K } & $0.0552^{* * *}$ & $0.0542 * * *$ & $0.0554 * * *$ & $0.0560^{* * *}$ \\
\hline & $(3.06)$ & $(2.98)$ & $(3.05)$ & $(3.11)$ \\
\hline \multirow{2}{*}{$\mathrm{S} / \mathrm{K}$} & $0.0108^{* * *}$ & $0.0108^{* * *}$ & $0.0107 * * *$ & $0.0109^{* * *}$ \\
\hline & $(4.63)$ & $(4.64)$ & $(4.64)$ & $(4.68)$ \\
\hline \multirow{2}{*}{$\mathrm{CF} / \mathrm{K}$} & $0.2590^{* * *}$ & -1.0078 & $1.0823 * * *$ & $2.3937 * *$ \\
\hline & $(7.47)$ & $(-0.45)$ & $(3.64)$ & $(2.35)$ \\
\hline \multirow{2}{*}{$\mathrm{CF} / \mathrm{K} * \mathrm{FRE}$} & & 0.1997 & $-0.3523 * * *$ & $-0.2344 * *$ \\
\hline & & $(0.57)$ & $(-2.77)$ & $(-2.09)$ \\
\hline R-square & 0.0814 & 0.0816 & 0.0846 & 0.0832 \\
\hline No. obs & 2503 & 2503 & 2503 & 2503 \\
\hline No. groups & 397 & 397 & 397 & 397 \\
\hline
\end{tabular}

Note: t-statistics are presented in the parentheses below the estimated coefficients $*, * *, * * *$ indicates significance at the $10 \%, 5 \%, 1 \%$, respectively

Table 3b. Regression Result (by firms' size)

\begin{tabular}{|c|c|c|c|}
\hline & $\begin{array}{l}\text { Economic } \\
\text { freedom }\end{array}$ & $\begin{array}{r}\text { Capital } \\
\text { freedom }\end{array}$ & $\begin{array}{l}\text { Domestic } \\
\text { credit } \\
\text { freedom }\end{array}$ \\
\hline \multirow{2}{*}{ _cons } & $38.8669 * * *$ & $29.5796 * * *$ & $47.1841 * * *$ \\
\hline & $(5.36)$ & $(3.86)$ & $(5.53)$ \\
\hline \multirow{2}{*}{ L.I/K } & $0.0505^{* * *}$ & $0.0522 * * *$ & $0.0524 * * *$ \\
\hline & $(2.80)$ & $(2.90)$ & $(2.93)$ \\
\hline \multirow{2}{*}{$\mathrm{S} / \mathrm{K}$} & $0.0114 * * *$ & $0.0113 * * *$ & $0.0115^{* * *}$ \\
\hline & (4.88) & $(4.87)$ & (4.91) \\
\hline \multirow{2}{*}{$\mathrm{CF} / \mathrm{K}$} & -1.1285 & $1.0685^{* * *}$ & $2.3284 * *$ \\
\hline & $(-0.50)$ & (3.65) & $(2.29)$ \\
\hline \multirow{2}{*}{$\begin{array}{c}\mathrm{CF} / \mathrm{K}^{*} \\
\text { FRE*LARGE }\end{array}$} & 0.2413 & $-0.2870^{* *}$ & $-0.2119^{*}$ \\
\hline & $(0.67)$ & $(-2.27)$ & $(-1.87)$ \\
\hline \multirow{2}{*}{$\begin{array}{c}\mathrm{CF} / \mathrm{K}^{*} \\
\text { FRE*SMALL }\end{array}$} & 0.2153 & $-0.3556 * * *$ & $-0.2296^{* *}$ \\
\hline & $(0.60)$ & $(-2.82)$ & $(-2.06)$ \\
\hline R-square & 0.0844 & 0.0872 & 0.0859 \\
\hline $\begin{array}{c}\text { No. } \\
\text { Observations } \\
\end{array}$ & 2503 & 2503 & 2503 \\
\hline No. groups & 397 & 397 & 397 \\
\hline
\end{tabular}

Note: t-statistics are presented in the parentheses below the estimated coefficients

$*, * *, * * *$ indicates significance at the $10 \%, 5 \%, 1 \%$, respectively

\section{Conclusions}

As many economists still debate about the economic freedom issues, creation of the economic freedom index benefits numerous studies on the consequence of economic freedom. This paper examines the effect of economic freedom and major sub-components of the freedom index on the investment of the domestic firms in Vietnam. Our result shows that improvements in domestic credit freedom and capital freedom are associated with being less dependent on internal cash flow. In addition, we suggest that removing barriers to capital movement and deregulating the domestic credit market increase the firms' investment in Vietnam.

\section{References}

Beck, T., Demirgüç-Kunt, A. S. L. I., \& Maksimovic, V. (2005). Financial and legal constraints to growth: does firm size matter? The Journal of Finance, 60(1), 137-177. https: //doi.org/10.1111/j.1540-6261.2005.00727.x

Bjørnskov, C. (2016). Economic freedom and economic crises. European Journal of Political Economy, 45, 11-23. https://doi.org/10.1016/j.ejpoleco.2016.08.003

Calomiris, C., \& Hubbard, R. (1995). Internal Finance and Investment: Evidence from the Undistributed Profits Tax of 
1936-37. The Journal of Business, 68(4), 443-482. Retrieved from www.jstor.org/stable/2353142

Cleary, S. (1999). The Relationship between Firm Investment and Financial Status. The Journal of Finance, 54(2), 673-692. https://doi.org/10.1111/0022-1082.00121

De Haan, J., \& Sturm, J.-E. (2000). On the relationship between economic freedom and economic growth. European Journal of Political Economy, 16(2), 215-241. https://doi.org/10.1016/S0176-2680(99)00065-8

Erum, N., Hussain, S., \& Yousaf, A. (2016). Foreign direct investment and economic growth in Saarc countries. Journal of Asian Finance, Economics and Business, 3(4), 57-66. https://doi.org/10.13106/jafeb.2016.vol3.no4.57

Gilchrist, S., \& Himmelberg, C. (1998). Investment: Fundamentals and Finance. NBER Macroeconomics Annual, 13, 223-262. https://doi.org/10.1086/ma.13.4623744

Gochoco-Bautista, M. S., Sotocinal, N. R., \& Wang, J. (2014). Corporate Investments in Asian Markets: Financial Conditions, Financial Development, and Financial Constraints. World Development, 57, 63-78. https://doi.org/10.1016/j.worlddev.2013.11.017

Gwartney, J. D., Lawson, R., \& Block, W. (1996). Economic freedom of the world, 1975-1995. The Fraser Institute. Retrieved November 10, 2019, from: https://www.fraserinstitute.org/sites/default/files/EconomicFr eedomoftheWorld1975-1995.pdf

Hall, J. C., \& lawson, R. A. (2014). Economic freedom of the world: an accounting of the literature. Contemporary Economic Policy, 32(1), 1-19. https://doi.org/10.1111/coep.12010

Harrison, A. E., Love, I., \& McMillan, M. S. (2004). Global capital flows and financing constraints. Journal of Development Economics, 75(1), 269-301. https://doi.org/10.1016/j.jdeveco.2003.10.002

Harrison, A. E., \& McMillan, M. S. (2003). Does direct foreign investment affect domestic credit constraints? Journal of International Economics, 61(1), 73-100. https://doi.org/10.1016/S0022-1996(02)00078-8

Héricourt, J., \& Poncet, S. (2009). FDI and credit constraints: Firm-level evidence from China. Economic Systems, 33(1), 121. https://doi.org/10.1016/j.ecosys.2008.07.001
Kaplan, S. N., \& Zingales, L. (1997). Do investment-cash flow sensitivities provide useful measures of financing constraints? The Quarterly Journal of Economics, 112(1), 169-215. https://doi.org/10.1162/003355397555163

Koo, J., \& Maeng, K. (2005). The effect of financial liberalization on firms' investments in Korea. Journal of Asian Economics, 16(2), 281-297. https://doi.org/10.1016/j.asieco.2005.02.003

Love, I. (2003). Financial development and financing constraints: International evidence from the structural investment model. The Review of Financial Studies, 16(3), 765-791. https://doi.org/10.1093/rfs/hhg013

Nguyen, T. N. L., \& Nguyen, V. C. (2020). The Determinants of Profitability in Listed Enterprises: A Study from Vietnamese Stock Exchange. Journal of Asian Finance, Economics and Business, 7(1), 47-58.

https://doi.org/10.13106/jafeb.2020.vol7.no1.47

Modigliani, F., \& Miller, M. H. (1958). The Cost of Capital, Corporation Finance and the Theory of Investment. The American Economic Review, 48(3), 261-297. https://www.jstor.org/stable/1809766

Mulier, K., Schoors, K., \& Merlevede, B. (2016). Investmentcash flow sensitivity and financial constraints: Evidence from unquoted European SMEs. Journal of Banking \& Finance, 73, 182-197. https://doi.org/10.1016/j.jbankfin.2016.09.002

Musso, P., \& Schiavo, S. (2008). The impact of financial constraints on firm survival and growth. Journal of Evolutionary Economics, 18(2), 135-149. https://doi.org/10.1007/s00191-007-0087-z

Stiglitz, J. E. (2009). The anatomy of a murder: who killed America's economy? Critical Review, 21(2-3), 329-339. https://doi.org/10.1080/08913810902934133

Tran, N. H., \& Le, C. D. (2017). Financial conditions and corporate investment: Evidence from Vietnam. Pacific Accounting Review, 29(2), 183-203. https://doi.org/10.1108/PAR-07-2016-0066

Weber, S. (2010). Bacon: An effective way to detect outliers in multivariate data using Stata (and Mata). Stata Journal, 10(3), 331-338. https://doi.org/10.1177/1536867X1001000302

Zhang, R., \& Yin, H. (2018). Regional Financial Development, Firm Heterogeneity and Investment Efficiency. Journal of Asian Finance, Economics and Business, 5(4), 73-83. http://doi.org/10.13106/jafeb.2018.vol5.no4.73 


\section{Appendix}

A.1. Variable description

\begin{tabular}{|c|c|c|}
\hline Variable & Definition & Calculation \\
\hline $\mathrm{K}_{\mathrm{it}}$ & $\begin{array}{l}\text { Capital of firm } i \text { at } \\
\text { the beginning of the } \\
\text { period } t\end{array}$ & $\begin{array}{l}\text { Take the value of fixed } \\
\text { assets at the end of the } \\
\text { previous year }(\mathrm{t}-1) \text { from } \\
\text { the Balance sheet }\end{array}$ \\
\hline $\mathrm{I}_{\mathrm{it}}$ & $\begin{array}{l}\text { Investment of firm i } \\
\text { during period } t\end{array}$ & Kit+1+DEPRit-Kit \\
\hline $\mathrm{DEPR}_{\mathrm{it}}$ & $\begin{array}{l}\text { Depreciation of firm } \\
\text { i during period } t\end{array}$ & $\begin{array}{l}\text { (Accumulate depreciation } \\
\text { at year } \mathrm{t} \text { ) - (Accumulate } \\
\text { depreciation at year } \mathrm{t}-1)\end{array}$ \\
\hline $\mathrm{CF}_{\text {it }}$ & $\begin{array}{l}\text { Cashflow of firm i } \\
\text { during period t-1 }\end{array}$ & PATit-1+DERPit-1 \\
\hline $\mathrm{S}_{\mathrm{it}}$ & $\begin{array}{l}\text { Sales of firm i } \\
\text { during period } t\end{array}$ & $\begin{array}{l}\text { The value is taken from } \\
\text { the Income statement }\end{array}$ \\
\hline $\mathrm{PAT}_{\text {it }}$ & $\begin{array}{l}\text { Profit after tax of } \\
\text { firm i generated } \\
\text { during period } t\end{array}$ & $\begin{array}{c}\text { The value of Profit before } \\
\text { tax from the Income } \\
\text { statement }\end{array}$ \\
\hline
\end{tabular}

Source: www.cophieu68.vn and author calculation
A.2. List of industries

\begin{tabular}{|c|c|}
\hline No. & Industry \\
\hline $\mathbf{1}$ & Agriculture, Forestry, Fishing, and Hunting \\
\hline $\mathbf{2}$ & Mining \\
\hline $\mathbf{3}$ & Utilities \\
\hline $\mathbf{4}$ & Construction \\
\hline $\mathbf{5}$ & Real Estate \\
\hline $\mathbf{6}$ & Manufacturing \\
\hline $\mathbf{7}$ & Trade \\
\hline $\mathbf{8}$ & Transportation and Warehousing \\
\hline $\mathbf{9}$ & Information \\
\hline $\mathbf{1 0}$ & Services \\
\hline
\end{tabular}

Note. Industry classified refer to Vietstock (available at the website http://finance.vietstock.vn/) 